\title{
Gender Differences in Determinants of Customer Satisfaction in Beauty and Cosmetic E-commerce*
}

\author{
Thuan Thi Nhu NGUYEN ${ }^{1}$
}

Received: July 30, 2020 Revised: August 23, 2020 Accepted: September 05, 2020

\begin{abstract}
This study investigates the gender differences in determinants of customers' satisfaction when purchasing online beauty and cosmetics products in Vietnamese market. To do so, we construct a data set via online survey of 419 Vietnamese customers including both males and females, and examine such sample using t-tests and multiple regressions. Our regression model is constructed based on our five-construct model including online shopping experience, customer service, external incentives, security and privacy, and personal characteristics. The t-tests results reveal that the mean difference of customer satisfaction (negative coefficient) between the two groups of customers (females and males) is statistically significant. This suggests that the purchasing satisfaction of male customers is significantly higher than that of their female counterparts. Similarly, we also find that male customers are more satisfied with their online shopping experience, customer service and external incentives offered by the online sellers than female peers. Furthermore, regression results for full sample show that, on average, the online shopping experience, customer service and external incentives are significantly and positively related to customer satisfaction. Yet, such positive effect of customer service on customer satisfaction is more likely for males while females' satisfaction is more positively influenced by security and privacy.
\end{abstract}

Keywords: Males, Females, Online Shopping, Customer Satisfaction, Beauty, Cosmetics

JEL Classification Code: C12, M15, M10, M31

\section{Introduction}

E-commerce businesses in Vietnam has been hurriedly growing in past recent years, which was mainly caused by a speedy growth of internet (online) shopping phenomenon. In revenue terms, the growth rate (CAGR) of e-commerce in Vietnam surged $30 \%$ in 2018 to reach a new high of about

\footnotetext{
*Acknowledgements:

[1] The author thanks very much to Tomas Bata University in Zlín for their continuous support and funding.

[2] The author also especially thanks to Professor Chovancová Miloslava, Dr Lubor Homolka, Editors Professor Jung Wan LEE and external reviewers for their valuable comments and feedback, so that the paper has been substantially improved and getting published.

${ }^{1}$ First Author and Corresponding Author. PhD Candidate, Faculty of Management and Economics, Tomas Bata University in Zlín, Czech Republic [Postal Address: TGM 5555, 760 01, Zlín, Czech Republic] Email: tthi_nhu@utb.cz
}

(c) Copyright: The Author(s)

This is an Open Access article distributed under the terms of the Creative Commons Attribution Non-Commercial License (https://creativecommons.org/licenses/by-nc/4.0/) which permits unrestricted non-commercial use, distribution, and reproduction in any medium, provided the original work is properly cited.
US $\$ 8$ billion. User penetration was recorded at about $56.7 \%$ in 2019 and is projected to reach $64.4 \%$ in the next four years (Linh, 2020). In addition, the number of Vietnamese internet users is anticipated to reach 67.8 million in 2021, making Vietnam become one of the biggest online markets worldwide. Importantly, physical businesses have been recently attempting to gain their competitive advantage by using e-commerce to interact with their customers (Lee \& Lin, 2005). In addition, new entrants or new competitors within online business sector can easily enter the market because of low entry barriers (Wang, Shen, \& Huang, 2016).

Undeniably, online shopping (OnS hereafter) in Vietnam has become a consumption habit of both female and male customers but more on the former. One living here may ascertain that OnS is an inherent part of their life, above and beyond the trend of $\mathrm{OnS}$ is proliferating around the world day by day. Moreover, the technology oriented, and technology founded economies appears to be redefining the ways of OnS. As consumers continue purchasing by directly visiting the physical stores and outlets, both virtual and e-commerce stores have become popular in parallel. Through OnS, consumers not only can save their time and energy, but 
may also feel more comfortable and convenient. If online marketers or internet marketers wants to be successful, they need to understand the customers as well as continuously innovative products. From the customer perspective, they have low switching costs to shop from one online store to another (Mutum, Ghazali, Nguyen, \& Arnott, 2014). Buying and selling have been widely transformed as many people fancy making their shopping from online stores rather than going to conventional markets. Furthermore, the online environment helps consumers obtain price and product information from various sellers more rapidly and easily than does the offline environment (Park \& Lennon, 2009; Shin \& Biocca, 2017; Yaylı \& Bayram, 2012).

Furthermore, customer satisfaction (CS hereafter) has been widely studied in a vast of market literature (e.g., Oliver \& Swan, 1989; Homburg, Kuester, Beutin, \& Menon, $2005)$ because the CS level is positively associated with economic consequences and corporate performance. CS, which is defined as "the consumer's fulfilment response", is "a judgment that a product or service feature, or the product or service itself, provided (or is providing) a pleasurable level of consumption-related fulfilment, including levels of under- or over-fulfilment" (Oliver, 1996, p.12). Customer experience and CS tend to be perceived and interpreted dissimilarly from person to person (Arnould \& Thompson, 2005). Their consumption rarely includes unilateral, supplyside manipulation of an experience which members of a homogeneous market segment has consumed and interpreted identically. In contrast, some types of customers seek out more complex experiences challenging them "to (re) interpret their identity and viewpoint of the world" (Firat \& Venkatesh, 1995). A crucial factor which can help to provide explanations for different perceptions and behaviours from person to person is whether the customers are female or male (Voss \& Cova, 2006). For example, females are more reluctant towards OnS. A better knowledge on the effect of gender differences on CS and determinants of CS is expected to give us a new insight into which "needs receive priority for which customers in somewhat complex service encounters" (Voss \& Cova, 2006, p.202). As such, online businesses are able to tailor their experience that enhance satisfaction and trigger salient to male as well as male customers towards beauty and cosmetics products.

Existing literature examining levels of CS between males and females has provided mixed findings. Some research (e.g., Carmel, 1985; Ross, Fleming, Fabes, \& Frankl, 1999) find that there are no significant differences in the CS level between male and female customers. Meanwhile, other studies (e.g., Buller \& Buller, 1987) have reported female customers tend to experience greater level of satisfaction than their male peers. Besides, there is still some literature (e.g., Bendall-Lyon \& Powers, 2002) showing an opposite result that males are more likely to be satisfied with quality and services than females over time. Particularly, the study of Voss and Cova (2006) proves that while females' satisfaction level is higher if they perceived a pleasurable level of value expressive attributes, that of male customers is higher if they perceived a pleasurable level of functional attributes. However, there is lack of research looking at the differential behaviour of males compared to females in the online beauty and cosmetics shopping while the demand of male customers towards beauty and cosmetics products has been significantly increased in recent years.

To the best of knowledge, there are no studies to date looking at the gender differences in determinants of CS when purchasing online beauty and cosmetics products in Vietnamese market. This study therefore seeks to extend existing work and fill theoretical gaps in gender marketing and CS literature, as well as online businesses or e-commerce marketing literature. We employ theories related to gender marketing and consumer behaviour or CS areas. Theses line of literature have emphasised that males and females are different in terms of image preferences and processing in response to message stimuli such as advertising appeals (e.g., Shapiro \& Mahajan, 1986; Meyers-Levy, 1988; Brunel \& Nelson, 2000; Putrevu, 2004). These studies have supported for the direct influences of service and product quality on CS following a consumption exchange. We, hence, continue attempting to extend these existing findings to date in both areas through an investigation of how males and females perceived towards CS and its determinants. We suppose that in marginally online businesses, males' satisfaction is influenced by their assessment towards perceived functional attributes while females' satisfaction on consuming beauty and cosmetics products is affected by their assessment towards perceived value-expressive attributes. Assessment requires both males' and females' customers to engage in evaluation of if the exchange merited the social, economic, functional and psychological risks involved (Colbert, 2003). Arguably, differences in CS and its determinants between two genders can be explained by their differences in brand or image preferences, priorities and purchasing purposes, and processing strategies, as well as their perceptions of quality of the products and core services provided by the online businesses.

Over last more than twenty years, the innovation in the beauty and cosmetic industry has made it possible to produce a wide range of products to protect and moisturize the skin, thus helping females (or even males) consumers achieve natural-looking beauty and further raising the levels of personal hygiene. This beauty sector is also an important and valuable global sector. Although it is competitive, it offers an opportunity for new entrants and welcomes competitors. Therefore, it contributes to the economic national growth 
and generates global income. Interestingly, the beauty and cosmetics industry were one of the industries that survived during global crises, implying a high demand of its products.

This study contributes to the strand of CS literature (e.g., Rita, Oliveira, \& Farisa, 2019; Chiang \& Dholakia, 2003; Liebermann \& Stashevsky, 2009; Klerk \& Ampousah, 2002; Giao, Hang, Son, Kiem, \& Vuong, 2020; Giao, Thy, Vuong, Tu, Vinh \& Lien, 2020; Nguyen, Pham, Tran, \& Pham, 2020; Nguyen, Phan, Le, \& Nguyen, 2020) and consumer behaviour for cosmetics (Liu, Lin, Lee, \& Deng, 2013). Typically, Giao, Hang, Son, Kiem, and Vuong (2020) examine the tourists' satisfaction towards Bao Loc city in Vietnam, and they show three factors affecting the tourists' satisfaction, which include responsiveness, reliability, and empathy. Giao, Thy, Vuong, Tu, Vinh, and Lien (2020) also place their research on the CS, more specifically, they examine factors influencing CS with less than container load cargo services of logistics companies in Ho Chi Minh City (Vietnam). They have identified six important factors positively affect CS, which consists of service process, image, resource, price, management, and outcomes. Furthermore, Nguyen, Pham, Tran, and Pham (2020) investigate the effects of service quality, CS and switching costs on customer loyalty of e-banking in commercial banks in Vietnam. They find that five factors, which include service quality in e-banking reliability, responsiveness, service capacity, empathy and tangibility, exert positive influence on CS.

Last but not least, Nguyen, Phan, Le, and Nguyen (2020) examine determinants of e-government satisfaction in Hanoi (Vietnam) and their potential effects. Basically, they find six external factors which is significantly relevant to e-government satisfaction. These are efficiency, trust, reliability, convenience, citizen support, and transparency. They also find four control factors which is related to the satisfaction, that are gender, age, educational level and Internet frequency. After leveraging all of these previous studies on CS in different contexts in Vietnam, we believe that our study is the first to examine differences between male and female customers regarding their satisfaction for purchasing online beauty and cosmetics products in Vietnam and its determinants. Our findings provide valuable implications to business owners and managers in Beauty and Cosmetics OnS sector in Vietnamese market. They are also expected to enhance the awareness of online businesses about customer satisfaction for buying beauty and cosmetics products. They can hence establish appropriate marketing strategy to this unique segment, which tends to be significantly increased in years to come.

\section{Literature Review}

Prior studies (Kaufman \& Rousseeuw, 2009) have highlighted some important variables particularly demographic factors (i.e., gender, age, income, education, tastes, habit, routines, social norms and expectations, dominant cultural values) which are potentially associated with customers' behaviour as well as their satisfaction. Typically, different gender (i.e., males versus females) has different consuming behaviour towards products and services (Kotze, Anderson, \& Summerfield, 2016; Anderson \& Fornell, 2000). Yet this does not suggest that customers with same gender (or age, etc.) reveal same psychological characteristics as these might be different depending on individuals' own interests, habit and characters. More specifically, Hoyer and Maclnnis (2010) has defined gender as a set of characteristics differentiating male individuals from their female peers. They expect that these two legal genders differ each other about several aspects comprising of their personal trait, attitude as well as activities that have significant linkage with customer behaviour and satisfaction. They also have dissimilar observations and viewpoints towards life, environment, society, politics, culture, and processes. Therefore, male and female customers are likely to show their different judgements and overall consuming and purchasing satisfaction (Karatepe, 2011; Rodgers \& Harris, 2003).

In this study, we emphasize that the trend of purchasing beauty and cosmetics has been substantially changed over time. In the past, the majority of beauty and cosmetics products made have feminine features, however, in recent decades, these lines of products suits both females and males resulting in the rise of male consumption and purchasing on beauty and cosmetics. The demand of taking care of face and body of men seems to be not lower than that of women, and this has become a normal thing in daily life. People are more and more open-minded, and they accept any "unnormal" or not traditional things, typically in developing countries like Vietnam. Manufacturers in this beauty sector, therefore, have tried to catch the hot trend by increasing the volume of beauty and cosmetics products for men (e.g., Nivea for men). These products then have transferred to in-store as well as online sellers, and ultimately passed to customers. However, we argue that the $\mathrm{OnS}$ today is an exciting activity for both females than males. This is evident by the E-commerce survey conducted by the Vietnamese Ministry of Industry and Trade in 2013, which reports several interesting figures: 59\% females and $41 \%$ males shopped online products; $61 \%(51 \% ; 45 \% ; 19 \%)$ of them bought their online products via websites of online sellers, group-on websites, forums/social networks, and e-commerce trading floor, respectively. Among these products, beauty and cosmetics are one of the most popular lines of products for online shoppers.

Some studies have argued that the purposes for online shopping between male and females might be dissimilar (e.g., Fraj \& Martinez, 2006). While the former (i.e. male customers) has special interests and attention on key online 
product functions, the latter (i.e. female customers) tends to see online shopping as their own interests as well as a social need. Furthermore, these two groups of gender reveal their difference in expectation, want, need, lifestyle, and so on, which in turn, affects their difference in consumption behaviour and satisfaction. One of good illustrations for this is that females pay more attention on either personally relevant information or information relevant to others or both. As such, they tend to get involved in a more detailed and more in-depth examination of a message, and ultimately base on product attributes to make their extended decisions. On a contrary, male customers tend to focus solely on the personally related information. For example, they might utilise simpler heuristics and process information based on few details (Hoyer \& Maclnnis, 2010; Karatepe, 2011). Taken together, this current research makes a theoretical prediction that female online shoppers are more likely to focus their attention on the products' quality (i.e., detailed consideration and evaluation on every single aspect of the purchased products) than their male counterparts (i.e., focused on overall products). This leads to the systematic difference in purchasing satisfaction between men and women. In other words, gender plays a vital role in consumer behaviour and CS.

Moreover, shoppers who are females and with compulsive purchasing are more likely to be affected by negative emotions due to their perceived stress which plays a vital role in online compulsive buying among women (Hetzel-Riggin \& Pritchard, 2011). They are also suffered from greater stress levels which are more prone to use negative coping strategies (Anshel, Kang, \& Miesner, 2010). An example for this is that female customers who are in stressful period tends to safeguard their residual resources rather than consuming the products. As such, behaviour of these people could be more stress-avoiding or situation-denying. Furthermore, a growing research has placed on the adverse effect of selfesteem on the individuals' negative coping strategies as well as online compulsive buying (e.g., Dittmar, 2005; Roberts, Manolis, \& Pullig, 2014).

Taken together, we anticipate that female customers have greater expectation of the beauty and cosmetics products which are purchased via online channels, than male customers who have much lower perceptions on detailed characteristics of those products. This in turn, influences the level of CS. More specifically, although we expect that male customers perceive customer service quality and external incentives better than female customers, but they may perceive privacy and security more important as men are often more concerned of technological aspects and information protection which they are more understood about and more interested in. Regarding the previous online experience, we also predict that male customers have more positive experience than their female counterparts because they are less likely to place their attention on details and characteristics of products. In other words, it may be easier to make males satisfied with the purchasing online as $\mathrm{OnS}$ is convenient for them, especially many Asian or Vietnamese males are still not comfortable to shop in physical stores because beauty and cosmetics products have long been perceived to be those for females rather than males. OnS helps them to overcome this challenge and hence, they tend to do more shop and consume more these types of products. Following our selfconstructed five-construct theoretical framework in another paper, we have added the expected effects of gender on the relationships between constructs and CS variable (Figure 1). In term of econometrics, gender is measured as a dummy factor which takes value of one if the observed respondent is female and otherwise zero. Accordingly, the hypothesis of this study is stated in the alternative form as below:

H1: Male customers'satisfaction tends to be significantly higher than that of their female counterparts.

H2: There is a positive relationship between OnS experience and customer satisfaction; however, this is more likely for male customers than their female counterparts.

H3: There is a positive relationship between seller/ customer service and customer satisfaction; however, this is more likely for male customers than their female counterparts.

H4: There is a positive relationship between external incentives and customer satisfaction; however, this is more likely for male customers than their female counterparts.

H5: There is a positive relationship between security/ privacy and customer satisfaction; however, this is less likely for male customers than their female counterparts.

\section{Research Methods and Materials}

\subsection{Survey and Data Collection}

In the survey, four main sections are designed: Section 1 includes the basic information or personal characteristics of the respondents (PC). Section 2 consists of information related to OnS experiences (OSE) of the respondents. Sector 3 look at the sellers or customers' service (SS). Section 4 and 5 explores the external incentives (EI) and security and privacy (SP). Section 5 looks at the satisfaction of the respondents (CS) to buy an online beauty and cosmetics products.

\subsection{Empirical Models}

To address our research questions, empirical models (1), (2a) and (2b) have been established based on the research 
framework which is designed by following previous studies in $\mathrm{CS}$ in $\mathrm{OnS}$ sector and in $\mathrm{OnS}$ sector for beauty and cosmetics (e.g., Liu, Lin, Lee, \& Deng, 2013; Chiang \& Dholakia, 2003; Rita, Oliveira, \& Farisa, 2019).

RQ1: What are the key factors affecting the customer satisfaction for purchasing online beauty and cosmetics products in Vietnam?

Full sample: $\mathrm{CS}_{\mathrm{i}}=\beta_{0}+\beta_{1} \mathrm{PC}_{\mathrm{i}}+\beta_{2} \mathrm{OSE}_{\mathrm{i}}+\beta_{3} \mathrm{SS}_{\mathrm{i}}+\beta_{4} \mathrm{EI}_{\mathrm{i}}$

$+\beta_{5} \mathrm{SP}_{\mathrm{i}}+\varepsilon_{\mathrm{it}}$

RQ2: Are there any differences between female and male customers?

Female sample only: $\mathrm{CS}_{\mathrm{i}}=\beta_{0}+\beta_{1} \mathrm{PC}_{\mathrm{i}}+\beta_{2} \mathrm{OSE}_{\mathrm{i}}+\beta_{3} \mathrm{SS}_{\mathrm{i}}$

$+\beta_{4} \mathrm{EI}_{\mathrm{i}}+\beta_{5} \mathrm{SP}_{\mathrm{i}}+\varepsilon_{\mathrm{it}}$

Male sample only: $\mathrm{CS}_{\mathrm{i}}=\beta_{0}+\beta_{1} \mathrm{PC}_{\mathrm{i}}+\beta_{2} \mathrm{OSE}_{\mathrm{i}}+\beta_{3} \mathrm{SS}_{\mathrm{i}}$

$+\beta_{4} \mathrm{EI}_{\mathrm{i}}+\beta_{5} \mathrm{SP}_{\mathrm{i}}+\varepsilon_{\mathrm{it}}$

\section{Dependent variable:}

Dependent variables include consumer satisfaction for online beauty and cosmetics. Customer satisfaction is measured by overall quality, customer satisfaction, customer trust, and word of mouth, and customer intention. The survey design of this research will follow the relevant literature and research framework (e.g., Liu, Lin, Lee, \& Deng, 2013; Chiang \& Dholakia, 2003). Prior study shows that the Likert scale is the most widely applied approach to score the survey. Therefore, in this study, the Likert scale is still used to rank the agree level of participants to questions regarding attitude, subjective norm and brand equity towards energy drink purchase intention. There are three common types of Likert scale including 5-point, 7-point and 10-point. This study employs 5-point Likert sale to measure the variables, with 1 meaning "strongly disagree; 2 meaning "disagree"; 3 meaning "average"; 4 meaning "agree"; 5 meaning "strongly agree".

\section{Independent variables:}

By reviewing previous literature regarding potential factors influencing CS in OnS sector, this study has identified seven groups of independent variables which are: Personal characteristics including demographic variables (i.e., gender; Age; Single Mothers; Marital Status; Occupation; Education; Monthly family income); OnS experience (i.e., Having OnS experience; no OnS experience; Having OnS experience for beauty and cosmetics); Seller service (i.e. Ordering; payment method; delivery/fulfilment; guarantee; website design and service); External incentives (i.e. Price, Promotion; Product attributes; Product Quality; Brand; Source of opinion); Security/privacy (i.e. Security; Privacy). Table 1 reports dimensions and variables used in our study.

\section{Data Analysis Procedure}

In order to achieve the purposes of this current study and examine hypotheses, STATA 16 will be used to analyse the collected data.

Table 1: Dimensions and variables

\begin{tabular}{|c|c|c|}
\hline Variables & Elements & Source \\
\hline \multicolumn{3}{|l|}{ Dependent variables } \\
\hline $\begin{array}{l}\text { Consumer } \\
\text { satisfaction }\end{array}$ & $\begin{array}{l}\text { Overall quality; Customer satisfaction; } \\
\text { Customer trust; Word of mouth; Customer } \\
\text { intention }\end{array}$ & $\begin{array}{l}\text { Liu, Lin, Lee, \& Deng (2013); Chiang \& Dholakia } \\
\text { (2003); Rita, Oliveira, \& Farisa (2019) }\end{array}$ \\
\hline \multicolumn{3}{|c|}{ Independent variables } \\
\hline $\begin{array}{l}\text { Personal } \\
\text { characteristics }\end{array}$ & $\begin{array}{l}\text { Demographic variables: Gender; Age; } \\
\text { Single Mothers; Marital Status; Occupation; } \\
\text { Education; Monthly family income; }\end{array}$ & \multirow{5}{*}{$\begin{array}{l}\text { Liu, Lin, Lee, \& Deng (2013); Chiang \& Dholakia } \\
\text { (2003); Rita, Oliveira, \& Farisa (2019) }\end{array}$} \\
\hline OnS experience & $\begin{array}{l}\text { Having OnS experience; No OnS experience; } \\
\text { Having OnS experience for beauty and } \\
\text { cosmetics }\end{array}$ & \\
\hline Seller service & $\begin{array}{l}\text { Ordering; Payment method; Delivery/ } \\
\text { fulfilment; Guarantee; Website design; Service }\end{array}$ & \\
\hline External incentives & $\begin{array}{l}\text { Price; Promotion; Product attributes; Product } \\
\text { Quality; Brand; Source of opinion }\end{array}$ & \\
\hline Security/privacy & Security; Privacy & \\
\hline
\end{tabular}




\subsection{Descriptive Statistics}

This study employs descriptive statistical analysis to analyse the characteristics of each variable in the empirical models. Indeed, we illustrate the respondents' profile by using descriptive statistics techniques in terms of frequency of distribution. Then the means and standard deviation of both independent and dependent variables will be presented.

\subsection{Factor Analysis and Scale Reliability}

To verify the dimensionality and reliability of constructs of this study, purification processes, including factor analysis and Cronbach's alpha analysis will be employed in this study. Factor analysis examined the basic pattern of the data. To maintain the most flexibility for this exploratory study, the decision was made to test each sub-dimension separately as a discrete construct. Coefficient Cronbach's alpha will be used to measure the internal consistency of each identified dimension.

EFA is a statistical method used to describe variability among observed and correlated variables (items) in a way to reduce the number of unobserved variables also called factors or components. EFA aim is to find those factors known as independent unobserved variables also labelled as latent variables. The principal component analysis (PCA) will be selected as the extraction method. The varimax rotation will be applied, which is an orthogonal rotation. The eigenvalue criteria $(\lambda>1)$ will be used to define the latent variables number for each sub-sample. During the iterative process, items with communality value smaller than 0.3 , and items with cross-loadings above absolute value of 0.4 will be removed. In addition, attention will be paid to the absence of multicollinearity, the nonzero correlations between items and sampling adequacy, which they will be controlled by the correlation matrix determinant that should be greater than 0.00001, the KMO statistic and Bartlett's test, respectively. Construct reliability of the items loading into a factor will be estimated by Cronbach's alpha (CA). These rules on how to find the best solution are given by Tabachnick and Fidell (2013). Analyses will be computed using STATA 16. Furthermore, we also employ Confirmatory Factor Analysis (CFA) to validate the constructs and items in questionnaire

Unreported results for EFA, PCA, CFA and CA show that our questionnaire and model constructs are all valid and reliable. We have reported these results in our separate study which developed and validated questionnaire and theoretical models. We will report these findings upon request.

\subsection{Hypothesis Testing}

In this study, empirical models will be tested through the multiple regressions using ordinary least square (OLS).
This is one of the most common methods in studies which tested factors or determinants. To employ this approach, one dependent variable and two or more independent variables need to be measured comprehensively and accurately (see Models 1-4). Diagnostics tests for heteroscedasticity and multicollinearity will be conducted to detect issues of data. In addition, robustness checks and sensitivity tests will be also implemented to check if the results are robust across different model specifications and measurements of variables. We find that there is no heteroscedasticity and multicollinearity in our models. Tables will be provided upon request.

Table 2 shows detailed information of demographic factors. Briefly, we find that the sample was predominantly female consumers $(65.4 \%)$ while the proportion of males in our sample accounts for $34.6 \%$. The highest percentage of both males $(50.3 \%)$ and females $(38.7 \%)$ are married, which is followed by $30.3 \%$ single males and $35 \%$ single females. In addition, $44.8 \%$ males and $52.6 \%$ females obtained a bachelor's degree. In term of income, the highest proportions of males earn salary in a range of 1832 million VND (26.9\%) and 10-18 million VND (24.1\%) while those of females have salary from 10-18 million VND (32.8\%) and 18-32 million VND (24.5\%). Only $1.4 \%$ males and $0.7 \%$ females have high income of over 80 million VND.

\section{Empirical findings}

\subsection{Descriptive Statistics}

Table 3 reports descriptive statistics on each construct of customer satisfaction (CS) and itself. First, we find that the mean and median of CS are 3.4443 and 3.5714, respectively. This shows that customer satisfaction score is higher than the average of 3 . For predicted determinants of CS, the mean (median; standard deviation) of OSE, SS, EI and SP are 3.6065 (3.75), 3.6216 (3.6667), 3.5631 (3.6667), and 3.6683 (3.6667) respectively. All our variables are made from 5-likert scales questions; hence, min-max range is from 1 to 5 . Higher value shows a positively increasing agreement of the statements. The remaining variables, which include CS1 to CS5, OSE1 to OSE7, SS1 to SS8, EI1 to EI10, and SP1 to SP3 presents detailed elements of CS, OSE, SS, EI and SP, respectively. They show the mean and median values falling within a range of 3.5 to 4 . The skewness and kurtosis results show relatively normal distribution of all observed variables. Moreover, due to the nature of these types of variables, we do not find any outliers, supported by $\mathrm{p} 1$ and $\mathrm{p} 99$ figures. 
Table 2: Demographic information of respondents

\begin{tabular}{|c|c|c|c|}
\hline & Male $\left(n_{\text {male }}=145\right)$ & Female $\left(n_{\text {female }}=274\right)$ & Total $(\mathrm{N}=419)$ \\
\hline \multicolumn{4}{|l|}{ Age range } \\
\hline $18-20$ & $10(6.9 \%)$ & $33(12.0 \%)$ & $43(10.3 \%)$ \\
\hline $21-25$ & $33(22.8 \%)$ & $69(25.2 \%)$ & $102(24.3 \%)$ \\
\hline $26-30$ & $57(39.3 \%)$ & $108(39.4 \%)$ & $165(39.4 \%)$ \\
\hline $31-35$ & $28(19.3 \%)$ & $44(16.1 \%)$ & $72(17.2 \%)$ \\
\hline Over 35 & $17(11.7 \%)$ & $20(7.3 \%)$ & $37(8.8 \%)$ \\
\hline \multicolumn{4}{|l|}{ Marital status } \\
\hline Single & $44(30.3 \%)$ & $96(35.0 \%)$ & $140(33.4 \%)$ \\
\hline Married & $73(50.3 \%)$ & $106(38.7 \%)$ & $179(42.7 \%)$ \\
\hline Others & $28(19.3 \%)$ & $72(26.3 \%)$ & $100(23.9 \%)$ \\
\hline \multicolumn{4}{|l|}{ Highest qualifications } \\
\hline High School Diploma & $21(14.5 \%)$ & $53(5.1 \%)$ & $74(17.7 \%)$ \\
\hline Bachelor's Degree & $65(44.8 \%)$ & $144(52.6 \%)$ & $209(49.9 \%)$ \\
\hline Masters' Degree & $47(32.4 \%)$ & $53(19.3 \%)$ & $100(23.9 \%)$ \\
\hline Doctoral Degree & $11(7.6 \%)$ & $10(19.3 \%)$ & $21(5.0 \%)$ \\
\hline Others & $1(0.7 \%)$ & $14(3.6 \%)$ & $15(3.6 \%)$ \\
\hline \multicolumn{4}{|l|}{ Salary } \\
\hline$<5$ million VND & $12(17.2 \%)$ & $39(14.2 \%)$ & $51(12.2 \%)$ \\
\hline $\begin{array}{l}\text { >=5 million VND; } \\
<10 \text { million VND }\end{array}$ & $25(17.2 \%)$ & $54(19.7 \%)$ & $79(18.9 \%)$ \\
\hline$>=10$ million VND; <18 million VND & $35(24.1 \%)$ & $90(32.8 \%)$ & $125(29.8 \%)$ \\
\hline$>=18$ million VND; <32 million VND & $39(26.9 \%)$ & $67(24.5 \%)$ & $106(25.3 \%)$ \\
\hline$>=32$ million VND; $<52$ million VND & $25(17.2 \%)$ & $21(7.7 \%)$ & $46(11.0 \%)$ \\
\hline$>=52$ million VND; <80 million VND & $7(4.8 \%)$ & $1(0.4 \%)$ & $8(1.9 \%)$ \\
\hline >=80 million VND & $2(1.4 \%)$ & $2(0.7 \%)$ & $4(1.0 \%)$ \\
\hline
\end{tabular}

Table 3: Descriptive Statistics

\begin{tabular}{|l|c|c|c|c|c|c|c|c|c|c|}
\hline Variables & $\mathbf{N}$ & Mean & $\mathbf{p 5 0}$ & Std. & Min & Max & Skewness & Kurtosis & p1 & p99 \\
\hline CS & 419 & 3.4443 & 3.5714 & 0.5822 & 1 & 5 & -0.8898 & 5.3174 & 1.5714 & 4.7143 \\
\hline OSE & 419 & 3.6065 & 3.7500 & 0.6123 & 1 & 5 & -0.9968 & 4.9773 & 1.6250 & 4.6250 \\
\hline SS & 419 & 3.6216 & 3.6667 & 0.5750 & 1 & 5 & -1.1528 & 5.8864 & 1.7778 & 4.7778 \\
\hline EI & 419 & 3.5632 & 3.6667 & 0.7162 & 1 & 5 & -0.9798 & 4.3039 & 1.3333 & 4.6667 \\
\hline SP & 419 & 3.6683 & 3.6667 & 0.5372 & 1 & 5 & -0.7903 & 6.0003 & 2.0000 & 4.7778 \\
\hline
\end{tabular}




\subsection{T-test Statistics Results}

Table 4 reports pair-sample t-test results for two subsamples including female and male customers. We find that the mean difference of customer satisfaction $(-0.1604)$ between the two groups of customers is statistically significant, that is, male customers (3.7732) have higher levels of customer satisfaction than female customers (3.6127). This is supported by t-value $(>2)$ and p-value $(<0.001)$.

\subsection{Multiple Regression Results}

To test our next four hypotheses ( $\mathrm{H} 2$ to $\mathrm{H} 5$ ) regarding the effects of each construct (OSE, SS, EI and SP) on customer satisfaction, and the influence of gender on such relationship, we further conduct multiple regressions via OLS approach with robust standard errors. To observe if there are any differences between males and females towards determinants of CS, beside testing for full sample (Table 5,
Panel A), we also test for female sub-sample (Table 5, Panel B) and male sub-sample (Table 5, Panel C). In Panel A, we find that on average, OSE, SS and EI are significantly and positively associated with customer satisfaction (CS). These are consistent with our hypotheses.

Table 5, Panel B and C compares the results of determinants of CS between female and male groups of customers. We first find that there is a positive relationship between seller/ customer service experience and CS for full sample, however, this is more likely for male customers than their female counterparts. This is consistent with $\mathrm{H} 3$ and evident by the insignificant coefficient on SS in Panel B (Females) but significantly positive coefficient on SS in Panel C (Males). In addition, we also find a positive relationship between security/ privacy and customer satisfaction in female sub-sample but not in male sub-samples, therefore, we can conclude that there is a positive relationship between security/privacy and customer satisfaction; however, this is less likely for male customers than their female counterparts. This provides support for H5.

Table 4: Pair-sample t-test results

\begin{tabular}{|c|c|c|c|c|}
\hline & Female & Male & Diff & t-value ( $p$-value) \\
\hline CS & 3.6127 & 3.7732 & -0.1604 & $\begin{array}{c}-2.9349 * * \\
(0.0018)\end{array}$ \\
\hline OSE & 3.4098 & 3.5094 & -0.0996 & $\begin{array}{c}-1.7464^{* *} \\
(0.0408)\end{array}$ \\
\hline SS & 3.5675 & 3.6802 & -0.1127 & $\begin{array}{c}-1.8940 * * \\
(0.0295)\end{array}$ \\
\hline El & 3.5953 & 3.6713 & -0.0760 & $\begin{array}{l}-1.3332^{*} \\
(0.0917)\end{array}$ \\
\hline SP & 3.5633 & 3.5632 & 0.0000 & $\begin{array}{c}0.0005 \\
(0.4998)\end{array}$ \\
\hline
\end{tabular}

Note: ${ }^{* * *},{ }^{* *}$ and ${ }^{*}$ indicates significant at $1 \%, 5 \%$ and $10 \%$ level of significance based on t-statistics

Table 5: OLS regression results

\begin{tabular}{|c|c|c|c|c|c|c|}
\hline \multirow[t]{2}{*}{ Dependent: CS } & \multicolumn{2}{|c|}{ Panel A: Full sample } & \multicolumn{2}{|c|}{ Panel B: Female Sub-sample } & \multicolumn{2}{|c|}{ Panel C: Male sub-Sample } \\
\hline & Coefficient & $\begin{array}{c}t \text {-value } \\
(p \text {-value })\end{array}$ & Coefficient & $\begin{array}{c}t \text {-value } \\
(p \text {-value) }\end{array}$ & Coefficient & $\begin{array}{c}t \text {-value } \\
(p \text {-value })\end{array}$ \\
\hline $\operatorname{OSE}\left(\beta_{2}\right)$ & $0.1820^{* * *}$ & $3.45(0.001)$ & $0.1191^{* *}$ & $2.12(0.035)$ & $0.1792^{*}$ & $1.67(0.097)$ \\
\hline$S S\left(\beta_{3}\right)$ & $0.1438^{* *}$ & $2.55(0.011)$ & 0.0929 & $1.53(0.128)$ & $0.2194^{*}$ & $1.880 .062)$ \\
\hline$E I\left(\beta_{4}\right)$ & $0.2636^{\star * *}$ & $4.48(0.000)$ & $0.3242^{* * *}$ & $4.59(0.000)$ & $0.1969^{*}$ & $1.95(0.053)$ \\
\hline$S P\left(\beta_{5}\right)$ & 0.0339 & $0.85(0.395)$ & $0.1374^{* \star *}$ & $2.80(0.006)$ & -0.0773 & $-1.38(0.171)$ \\
\hline Constant $\left(\beta_{0}\right)$ & $1.4471^{* * *}$ & $5.31(0.000)$ & $1.2198^{* * *}$ & $4.23(0.000)$ & $1.8896^{* * *}$ & $3.24(0.001)$ \\
\hline Observations & \multicolumn{2}{|c|}{419} & \multicolumn{2}{|c|}{274} & \multicolumn{2}{|c|}{145} \\
\hline R-square & \multicolumn{2}{|c|}{0.3139} & \multicolumn{2}{|c|}{0.3914} & \multicolumn{2}{|c|}{0.2399} \\
\hline Wald Chi 2 & \multicolumn{2}{|c|}{$\begin{array}{c}19.30^{* * *} \\
(0.000)\end{array}$} & \multicolumn{2}{|c|}{$\begin{array}{c}18.67^{* * *} \\
(0.000)\end{array}$} & \multicolumn{2}{|c|}{$\begin{array}{l}6.48^{* * *} \\
(0.000)\end{array}$} \\
\hline
\end{tabular}

Note: ${ }^{* * *},{ }^{* *}$ and ${ }^{*}$ indicates significant at $1 \%, 5 \%$ and $10 \%$ level of significance based on t-statistics 


\subsection{Multiple Regression Results}

To additional check for our results in Table 5, in Table 6, we add into the empirical models some variables related to personal characteristics of online shoppers or demographic factors including gender (for full sample only - Panel A), age, marital status, education and income (For all samples - Panel A-C). For full sample (Panel A), we find similar results with those reported in Table 5. In other words, we find that OSE, SS and EI positively affect the overall CS. In addition, we further find a significant and positive relationship between GENDER and CS. This implies that male customers are likely to have higher level of CS than their female counterparts. Again, this is consistent with our first hypothesis. Furthermore, we find that online shoppers who have higher income tend to exhibit lower purchasing satisfaction. This may be due to the fact that richer people are more difficult to choose their favorable products and as such, they are less likely to satisfy with services and products they received. For Panel B and C, we find consistent results with the main findings.

\section{Discussion}

The t-test results are consistent with our first hypothesis $\mathrm{H} 1$ indicating that male customers' satisfaction tends to be significantly higher than that of their female counterparts. Other than being physically or biologically different, these two genders are dissimilar in terms of their trait, attitudes, and activities which have impact on consumer behaviour. Each gender, male and female, may observe the environment and processes differently and accordingly, show their judgements and satisfaction in dissimilar ways. Our finding is in line with the studies of Karatepe (2011) and Hoyer and Maclnnis (2010), and particularly Voss and Cova (2006) prove that while females' satisfaction level is higher if they perceived a pleasurable level of value expressive attributes, that of male customers is higher if they perceived a pleasurable level of functional attributes. With regards to Online Shopping Experience (OSE), Seller Services (SS) and External Incentives (EI), we also find that their mean of male customers is greater than that of female peers. Supported by significant t-test results, we conclude that male customers tend to be more satisfied with their shopping experience,

Table 6: OLS regression results

\begin{tabular}{|c|c|c|c|c|c|c|}
\hline \multirow[t]{2}{*}{$\begin{array}{l}\text { Dependent: } \\
\text { CS }\end{array}$} & \multicolumn{2}{|c|}{$\begin{array}{c}\text { Panel A: } \\
\text { Full sample }\end{array}$} & \multicolumn{2}{|c|}{$\begin{array}{c}\text { Panel B: } \\
\text { Female Sub-sample }\end{array}$} & \multicolumn{2}{|c|}{$\begin{array}{c}\text { Panel C: } \\
\text { Male sub-Sample }\end{array}$} \\
\hline & Coefficient & $\begin{array}{c}\text { t-value } \\
\text { (p-value) }\end{array}$ & Coefficient & $\begin{array}{c}\text { t-value } \\
\text { (p-value) }\end{array}$ & Coefficient & $\begin{array}{c}t \text {-value } \\
(p \text {-value })\end{array}$ \\
\hline $\operatorname{OSE}\left(\beta_{2}\right)$ & $0.1820^{* * *}$ & $3.49(0.001)$ & $0.1226^{* *}$ & $2.17(0.031)$ & $0.1888^{*}$ & $1.680(0.075)$ \\
\hline$S S\left(\beta_{3}\right)$ & $0.1416^{* *}$ & $2.57(0.011)$ & 0.1036 & $1.76(0.101)$ & $0.1982^{*}$ & $1.70(0.092)$ \\
\hline$E I\left(\beta_{4}\right)$ & $0.2634^{* * *}$ & $4.48(0.000)$ & $0.3230^{* * *}$ & $4.43(0.000)$ & $0.1944^{*}$ & $1.93(0.056)$ \\
\hline$S P\left(\beta_{5}\right)$ & 0.0257 & $0.63(0.527)$ & $0.1291^{* * *}$ & $2.59(0.010)$ & -0.0857 & $-1.36(0.176)$ \\
\hline $\operatorname{GENDER}\left(\beta_{1}\right)$ & $0.1139^{* *}$ & $2.23(0.026)$ & - & - & - & - \\
\hline$A G E\left(\beta_{1}\right)$ & 0.0292 & $1.00(0.318)$ & 0.0504 & $1.54(0.124)$ & -0.0324 & $-0.59(0.558)$ \\
\hline $\operatorname{MARITAL}\left(\beta_{1}\right)$ & 0.0191 & $0.48(0.629)$ & 0.0211 & $0.47(0.639)$ & 0.0087 & $0.12(0.908)$ \\
\hline $\begin{array}{l}\text { EDUCATION } \\
\left(\beta_{1}\right)\end{array}$ & 0.0444 & $1.46(0.144)$ & 0.0449 & $1.27(0.204)$ & 0.0971 & $1.53(0.129)$ \\
\hline $\operatorname{INCOME}\left(\beta_{1}\right)$ & $-0.0572^{* *}$ & $-2.39(0.017)$ & $-0.0701^{* * *}$ & $-2.83(0.005)$ & -0.0401 & $-0.76(0.449)$ \\
\hline Constant $\left(\beta_{0}\right)$ & $1.3570^{* * *}$ & $4.70(0.000)$ & $1.0953^{* * *}$ & $3.54(0.000)$ & $1.8729^{* * *}$ & $2.91(0.004)$ \\
\hline Observations & \multicolumn{2}{|c|}{419} & \multicolumn{2}{|c|}{274} & \multicolumn{2}{|c|}{145} \\
\hline R-square & \multicolumn{2}{|c|}{0.3392} & \multicolumn{2}{|c|}{0.4097} & \multicolumn{2}{|c|}{0.2533} \\
\hline Wald Chi 2 & \multicolumn{2}{|c|}{$\begin{array}{l}11.66^{* * *} \\
(0.000)\end{array}$} & \multicolumn{2}{|c|}{$\begin{array}{c}14.50^{* * *} \\
(0.000)\end{array}$} & \multicolumn{2}{|c|}{$\begin{array}{l}3.89^{* * *} \\
(0.000)\end{array}$} \\
\hline
\end{tabular}

Note: ${ }^{* * *},{ }^{* *}$ and ${ }^{*}$ indicates significant at $1 \%, 5 \%$ and $10 \%$ level of significance based on t-statistics 
services and external incentives provided by the online sellers such as ordering, payment method, delivery/fulfilment, guarantee policies, website design, price, promotion, product attributes, brand, and so on. These results are consistent with our argument that female customers have greater expectation of the beauty and cosmetics products which are purchased via online channels, than male customers who have much lower perceptions on detailed characteristics of those products. Simply, due to males' lower expectations and attention, they seem to be more satisfied. However, we do not find any significant difference in mean values between these two groups of customers regarding Security and Privacy (SP). This makes some senses because males often put their more attention on security and privacy as they tend to be attracted by technological issues.

When turning to the multiple regressions results, we find positive associations between OSE, SS and EI and customer satisfaction (CS). We explain that online shopping experience with the seller has effects on CS because if customers having good experience, their overall satisfaction might be increased. Similarly, online businesses need to deliver excellent customer services or SS which increase their loyalty. If better SS is provided to online shoppers, their favourable behavioural intentions are more likely (Brady \& Robertson, 2001). For example, SS can include the quality of website design where customers find the products' information as well as where they make their payments. Given that electronic service is one of the key factors determining the success of an online business (Sharma \& Lijuan, 2015). Furthermore, online shoppers often enjoy lower searching costs of products, expenses of negotiating traffic, spending time, and using energy to compare product prices. Therefore, online shopping offers them more convenient feeling including obtaining lower price and more accurate product information from different online sellers.

In addition, the speed of buying online products is more rapid than offline purchasing (Park \& Lennon, 2009; Shin \& Biocca, 2017; Yayl1 \& Bayram, 2012). Furthermore, promotion policy on price and others may also have significant impacts on CS and their purchasing decisions. It indeed creates some EI for them to buy online products. In the same line with this, Wang, Liao, Zhan, and Shi (2011) have argued that if customers are considering buying an online product between two competitive retailers, they may be favour of whom offers them more attractive promotion policy. This suggests that promotion and lower price plays vital roles in enhancing the consumers' perception of emotional value, and in turn, CS. Moreover, unique attributes and excellent quality of online beauty and cosmetics products also influence the customers' trust and enjoyment, which leads to their higher satisfaction. Finally, brands of products may be bias customers that they offer them more value in terms of quality. However, we find no effect of SP on CS.
However, we further find that the positive effect of SS on $\mathrm{CS}$ is more likely for males while females' satisfaction is more positively influenced by SP. We explain for these differences between males and females that men display more positive attitudes towards online shopping because they perceive the potential risks of purchasing online, familiarise with website design, and gain technology acceptance. Furthermore, females and males are different in terms of expectation, want, need, lifestyle, etc. which are reflected to their consumption behaviour (Fraj \& Martinez, 2006). For example, female customers are likely to pay attention to either personally relevant information or information relevant to others or both. They also tend to participate in a detailed and more in-depth investigation of a message and make extended decision based on product attributes. In contrast, male peers are normally more concerned about personally related information only. They utilise simpler heuristics and process information based on few details (Hoyer $\&$ Maclnnis, 2010; Karatepe, 2011). Therefore, we expect that female customers are more likely to place their emphasis on the products' quality than their male counterparts since they may have detailed consideration and evaluation on every single aspect of the purchased products, while the latter focuses on overall aspects. These difference lead to the systematic difference in purchasing satisfaction between men and women regarding CS determinants. For SP, it is easier to make female customers satisfied than their male peers as the former may not know well technological aspects. However, unfortunately the differences between males and females towards OSE and EI seem to be not clear. Indeed, we find positive effects of these factors on CS for both males and females.

\section{Conclusions}

In this study, we examine determinants of customer satisfaction when purchasing online beauty and cosmetics products in Vietnamese market, and further investigates if gender makes any difference. We use a constructed theoretical model of five constructs and a sample of 419 Vietnamese customers including both males and females. These constructs consist of online shopping experience, customer service, external incentives, security/privacy, and personal characteristics. For t-test results, we find that purchasing satisfaction of male customers tends to be significantly higher than that of their female counterparts. This is confirmed by multiple regressions results. In addition, we also find that male customers are more highly satisfied with their shopping experience, services and external incentives offered by the online sellers such as ordering, payment method, delivery/fulfilment, guarantee policies, website design, price, promotion, product attributes, brand, and so on. However, we do not find any significant difference in mean values between these two groups of customers regarding Security and Privacy (SP). This may be 
because male customers usually place their attention more on SP as such they are attracted by technological issues and realise risks related to SP. For OLS results, we find that on average, OSE, SS and EI are significantly and positively associated with customer satisfaction (CS) for full sample. However, conditioned on gender differences, male customer satisfaction is more likely to be affected by seller service while their female peers' satisfaction tends to be more positively influenced by security/privacy. Findings of our study may be of great interests to existing online businesses for beauty and cosmetics particularly new entrances.

Our research is limited to the control variables included in the empirical models. Therefore, for future study, researchers should include psychological factors and time factors to obtain a better overview. Moreover, a qualitative approach could be used to obtain a more in-depth findings explaining why there exists gender differences in customer satisfaction and its' determinants.

\section{References}

Anderson, E. W., \& Fornell, C. (2000). Foundations of the American customer satisfaction index. Total Quality Management, 11(7), 869-882. https://doi.org/10.1080/09544120050135425

Anshel, M. H., Kang, M., \& Miesner, M. (2010). The approachavoidance framework for identifying athletes' coping style as a function of gender and race. Scandinavian Journal of Psychology, 51(4), 341-349. https://doi.org/10.1111/j.14679450.2009.00796.x

Arnould, E. J., \& Thompson, C. J. (2005). Consumer culture theory (CCT): Twenty years of research. Journal of Consumer Research, 31(4), 868-882. https://doi.org/10.1086/426626

Bendall-Lyon, D., \& Powers, T. L. (2002). The impact of gender differences on change in satisfaction over time. Journal of Consumer Marketing, 19(1), 12-23. https://doi. org/10.1108/07363760210414925

Brady, M. K., \& Robertson, C. J. (2001). Searching for a consensus on the antecedent role of service quality and satisfaction: an exploratory cross-national study. Journal of Business Research, 51(1), 53-60. https://doi.org/10.1016/S01482963(99)00041-7

Brunel, F. F., \& Nelson, M. R. (2000). Explaining gendered responses to "help-self" and "help-others" charity ad appeals: The mediating role of world-views. Journal of Advertising, 29(3), 15-28. https://doi.org/10.1080/00913367.2000.10673614

Buller, M. K., \& Buller, D. B. (1987). Physicians' communication style and patient satisfaction. Journal of Health and Social Behavior, 28(4), 375-388. https://doi.org/10.2307/2136791

Carmel, S. (1985). Satisfaction with hospitalization: a comparative analysis of three types of services. Social Science \& Medicine, 21(11), 1243-1249. https://doi.org/10.1016/02779536(85)90273-4
Chiang, K. P., \& Dholakia, R. R. (2003). Factors driving consumer intention to shop online: an empirical investigation. Journal of Consumer Psychology, 13(1-2), 177-183. https://doi. org/10.1207/S15327663JCP13-1\&2_16

Colbert, F. (2003). Entrepreneurship and leadership in marketing the arts. International Journal of Arts Management, 6(1), 30-39. www.jstor.org/stable/41064806

Dittmar, H. (2005). Compulsive buying-a growing concern? An examination of gender, age, and endorsement of materialistic values as predictors. British Journal of Psychology, 96(4), 467-491. https://doi.org/10.1348/000712605X53533

Firat, A. F., \& Venkatesh, A. (1995). Liberatory postmodernism and the reenchantment of consumption. Journal of Consumer Research, 22(3), 239-267. https://doi.org/10.1086/209448

Fraj, E., \& Martinez, E. (2006). Influence of personality on ecological consumer behaviour. Journal of Consumer Behaviour: An International Research Review, 5(3), 167-181. https://doi.org/10.1002/cb.169

Giao, H. N. K., Hang, T. D., Son, L. T., Kiem, D., \& Vuong, B. N. (2020). Tourists' Satisfaction towards Bao Loc City, Vietnam. Journal of Asian Finance, Economics, and Business, 7(7), 269277. https://doi.org/10.13106/jafeb.2020.vol7.no7.269

Giao, H. N. K., Thy, N. T. A., Vuong, B. N., Tu, T. N., Vinh, P. Q., \& Lien, L. T. P. (2020). Customer Satisfaction with Less than Container Load Cargo Services in HoChiMinh City, Vietnam. Journal of Asian Finance, Economics and Business, 7(8), 333-344. https://doi.org/10.13106/jafeb.2020.vol7.no8.333

Hetzel-Riggin, M. D., \& Pritchard, J. R. (2011). Predicting problematic Internet use in men and women: the contributions of psychological distress, coping style, and body esteem. Cyberpsychology, Behavior, and Social Networking, 14(9), 519-525. https://doi. org/10.1089/cyber.2010.0314

Homburg, C., Kuester, S., Beutin, N., \& Menon, A. (2005). Determinants of customer benefits in business-to-business markets: a cross-cultural comparison. Journal of International Marketing, 13(3), 1-31. https://doi.org/10.1509/jimk.13.3.1

Hoyer, W. D., \& Maclnnis, D. J. (2010). Consumer Behavior (5th ed.). Mason, $\mathrm{OH}$ : South-Western, Cengage Learning.

Karatepe, O. M. (2011). Service quality, customer satisfaction and loyalty: the moderating role of gender. Journal of Business Economics and Management, 12(2), 278-300. https://www. ceeol.com/search/article-detail?id=330255

Kaufman, L., \& Rousseeuw, P. J. (2009). Finding groups in data: an introduction to cluster analysis (Vol. 344). Hoboken, NJ: John Wiley \& Sons.

Klerk, H. M. D., \& Ampousah, L. (2002). The physically disabled South African female consumer's problems in purchasing clothing. International Journal of Consumer Studies, 26(2), 93-101. https://doi.org/10.1046/j.1470-6431.2002.00209.x

Kotze, T. G., Anderson, O., \& Summerfield, K. (2016). Technophobia: Gender differences in the adoption of hightechnology consumer products. South African Journal of 
Business Management, 47(1), 21-28. https://hdl.handle. net/10520/EJC188606

Lee, G. G., \& Lin, H. F. (2005). Customer perceptions of e-service quality in online shopping. International Journal of Retail \& Distribution Management, 33(2), 161-176. https://doi. org/10.1108/09590550510581485

Liebermann, Y., \& Stashevsky, S. (2009). Determinants of online shopping: Examination of an early-stage online market. Canadian Journal of Administrative Sciences/Revue Canadienne des Sciences de l'Administration, 26(4), 316-331. https://doi.org/10.1002/cjas.121

Linh, D. H. (2020). Vietnam's Booming E-commerce Market. Singapore: ISEAS Yusof Ishak Institute. http://hdl.handle. net $/ 11540 / 11515$

Liu, W. Y., Lin, C. C., Lee, Y. S., \& Deng, D. J. (2013). On gender differences in consumer behavior for online financial transaction of cosmetics. Mathematical and Computer Modelling, 58(1-2), 238-253. https://doi.org/10.1016/j.mcm.2012.08.010

Meyers-Levy, J. (1988). The influence of sex roles on judgment. Journal of Consumer Research, 14(4), 522-530. https://doi.org/10.1086/209133

Mutum, D., Ghazali, E. M., Nguyen, B., \& Arnott, D. (2014). Online loyalty and its interaction with switching barriers. Journal of Retailing and Consumer Services, 21(6), 942-949. https://doi. org/10.1016/j.jretconser.2014.08.012

Nguyen, D. T., Pham, V. T., Tran, D. M., \& Pham, D. B. T. (2020). Impact of Service Quality, Customer Satisfaction and Switching Costs on Customer Loyalty. Journal of Asian Finance, Economics and Business, 7(8), 395-405. https://doi. org/10.13106/jafeb.2020.vol7.no8.395

Nguyen, T. T., Phan, D. M., Le, A. H., \& Nguyen, L. T. N. (2020). The Determinants of Citizens' Satisfaction of E-Government: An Empirical Study in Vietnam. Journal of Asian Finance, Economics and Business, 7(8), 519-531. https://doi. org/10.13106/jafeb.2020.vol7.no8.519

Oliver, R. L., \& Swan, J. E. (1989). Equity and disconfirmation perceptions as influences on merchant and product satisfaction. Journal of Consumer Research, 16(3), 372-383. https://doi.org/10.1086/209223

Oliver, R. (1996). Satisfaction: A Behavioral Perspective on the Customer. New York, NY: McGraw-Hill.

Park, M., \& Lennon, S. J. (2009). Brand name and promotion in online shopping contexts. Journal of Fashion Marketing and Management: An International Journal, 13(2), 149-160. https://doi.org/10.1108/13612020910957680

Putrevu, S. (2004). Communicating with the sexes: male and female responses to print advertisements. Journal of Advertising, 33(3), 51-62. https://doi.org/10.1080/00913367.2004.10639168
Rita, P., Oliveira, T., \& Farisa, A. (2019). The impact of e-service quality and customer satisfaction on customer behavior in online shopping. Heliyon, 5(10), e02690. https://doi.org/10.1016/j. heliyon.2019.e02690

Roberts, J. A., Manolis, C., \& Pullig, C. (2014). Contingent self-esteem, self-presentational concerns, and compulsive buying. Psychology \& Marketing, 31(2), 147-160. https://doi. org/10.1002/mar.20683

Rodgers, S., \& Harris, M. A. (2003). Gender and e-commerce: An exploratory study. Journal of Advertising Research, 43(3), 322329. https://doi.org/10.2501/JAR-43-3-322-329

Ross, L. W., Fleming, R. S., Fabes, K. J., \& Frankl, R. (1999). Gender effects on customer satisfaction with employment services. Career Development International, 4(5), 270-276. https://doi.org/10.1108/13620439910279752

Shapiro, R. Y., \& Mahajan, H. (1986). Gender Differences in Policy Preferences: A Summary of Trends from the 1960s to the 1980s. Public Opinion Quarterly, 50(1), 42-61. https://doi. org/10.1086/268958

Sharma, G., \& Lijuan, W. (2015). The effects of online service quality of e-commerce Websites on user satisfaction. The Electronic Library, 33(3), 468-485. https://doi.org/10.1108/ EL-10-2013-0193

Shin, D. H., \& Biocca, F. (2017). Health experience model of personal informatics: The case of a quantified self. Computers in Human Behavior, 69, 62-74. https://doi.org/10.1016/j. chb.2016.12.019

Tabachnick, B. G., \& Fidell, L. S. (2013). Using multivariate statistics. Upper Saddle River, NJ: Pearson.

Voss, Z. G., \& Cova, V. (2006). How sex differences in perceptions influence customer satisfaction: A study of theatre audiences. Marketing Theory, 6(2), 201-221. https://doi. org/10.1177/1470593106063983

Wang, J., Shen, Y., \& Huang, Y. (2016). Evaluating the regulatory scheme for internet finance in China: the case of peer-to-peer lending. China Economic Journal, 9(3), 272-287. https://doi.or $\mathrm{g} / 10.1080 / 17538963.2016 .1214381$

Wang, M., Liao, H., Zhan, Y., \& Shi, J. (2011). Daily customer mistreatment and employee sabotage against customers: Examining emotion and resource perspectives. Academy of Management Journal, 54(2), 312-334. https://doi.org/10.5465/ amj.2011.60263093

Yayl1, A., \& Bayram, M. (2012). E-WOM: The effects of online consumer reviews on purchasing decisions. International Journal of Internet Marketing and Advertising, 7(1), 51-64. https://doi.org/10.1504/IJIMA.2012.044958 